


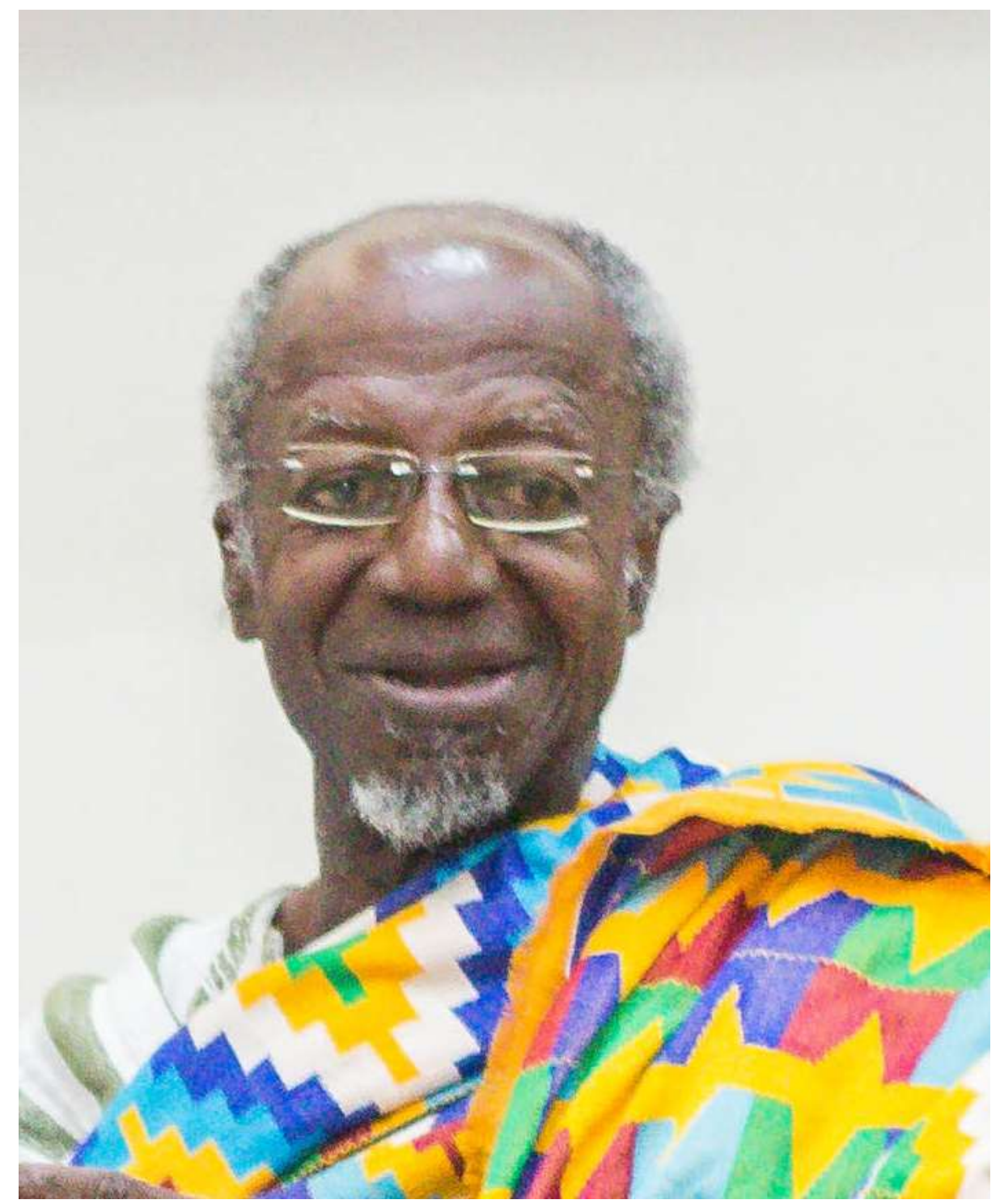

PROFESSOR ATTA GYAMFI BRITWUM 


\section{THE BILINGUAL LITERARY JOURNAL OF THE FACULTY OF ARTS UNIVERSITY OF CAPE COAST}

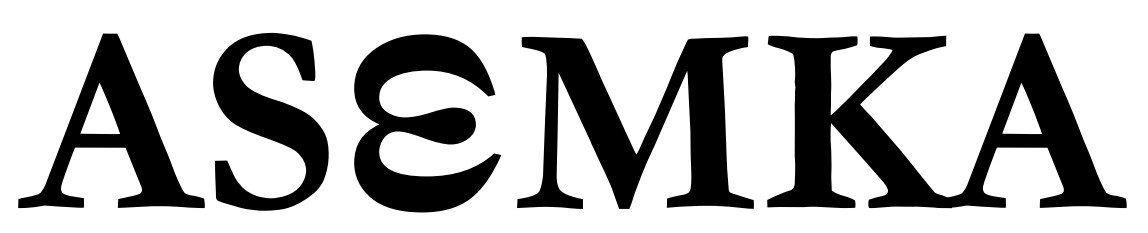

NUMBER 10

SEPTEMBER 2020

\section{EDITORIAL COMMITTEE}

Editor-in-Chief: Prof. Samuel Awuah-Nyamekye (Ph.D.)

Editor: $\quad$ Prof. Mawuloe Koffi Kodah (Ph.D.)

Associate Editors: Dr. Samuel Kwesi Nkansah

Dr. Mrs. Theresa Addai Munumkum

Dr. Isaac Mwinlaaru

Business Editor: Rev. Sr. Dr. Matilda Alice Nsiah

\section{EDITORIAL STAFF}

Mr. Stephen Owusu-Amoh

Mr. Isaac Kweku Grantson

\section{EDITORIAL ADVISORS}

Prof. Kwadwo Opoku-Agyemang, University of Cape Coast.

Prof. Joseph B. A. Afful, University of Cape Coast.

Prof. Raymond N. Osei, University of Cape Coast.

Prof. Richard V. Cudjoe, University of Cape Coast.

Prof. Victor K Yankah, University of Cape Coast.

Dr. Mousa Traore, University of Cape Coast. 


\section{ACKNOWLEDGEMENTS}

We acknowledge the contribution of the underlisted members of the Department of French who did preliminary editorial work on the papers:

Dr. Anthony Y.M. De-Souza (Chairman)

Prof. Raymond N. Osei

Prof. Mawuloe K. Kodah

Dr. Sylvester P. Krakue

Mr. Ofosu Addo-Danquah

Mr. Micheal Donkoh (Secretary)

\section{SUBSCRIPTION}

Assmka is published twice in the Academic year by the Faculty of Arts, University of Cape Coast. The annual out-of-Ghana subscription rate, including air-postage, is US\$29 for individuals, and US\$ 59 for institutions and libraries. Single issue rate for individuals is US\$18. Claims for copies not received must be made within three (3) months following an issue's publication. Correspondence should be addressed to:

The Editor, Assmka

Department of French

Faculty of Arts

College of Humanities and Legal Studies

University of Cape Coast

Cape Coast

Ghana, West Africa

Email: asemkajournal@ucc.edu.gh

\section{ADVERTISING}

Advertising rate, size specifications and related information are available upon request. Please, contact the General Editor for more information.

\section{SUBMISSIONS}

Assmka is an internationally-refereed journal of the Humanities. It publishes scholarly and imaginative articles in Literature, Language, and Culture generally, including, Orature, Film, Theatre, Music and Art. Essays, Interviews, Book Reviews, Poetry, Short Prose Fiction and Drama are welcome. Submitted manuscripts, in English and French, must be prepared in accordance with the most recent of APA or MLA style manual, where applicable. The author's identity and address may appear only on the cover- 
page and nowhere else within the submitted manuscript. All manuscripts should be submitted electronically through:

asemkajournal@ucc.edu.gh

Manuscript will be duly acknowledged within two (2) months of receiving them. Individuals whose works are accepted for publication may provide Assmka with a brief bio-data. The Editors cannot be held liable for lost or damaged manuscripts. Material published by Assmka does not necessarily represent the views of the Journal's Editors, Staff, Financial Supporters or the University of Cape Coast and its affiliates. These parties disavow any legal responsibility related to all submitted material.

\section{BACK ISSUES}

Back issues of Ascmka that are in stock may be ordered from the Editor at US\$20 per copy.

\section{GRANT SUPPORT}

Assmka is funded through grants from the Office of the Dean, Faculty of Arts; the Publications' Board; and the Office of the Vice-Chancellor, University of Cape Coast, Cape Coast, Ghana.

No part of this Journal may be reproduced, stored in a retrieval system, or transmitted in any manner whatsoever without express permission from the Editors, except in the case of brief quotations embodied in critical Articles and Reviews.

Copyright (C2020 by The Editors and The Faculty of Arts, University of Cape Coast. The cover and page design elements were inspired by the Adinkra symbols of Ghana. 


\section{DEDICATION \\ PROFESSOR ATTA GYAMFI BRITWUM}

Professor Britwum is a man of many parts. He is as much at home with Marxist Economic Theory and Feminist Sociological Thoughts, as he is with French and Francophone Literatures. He is a great teacher and Administrator of international acclaim. The Editors dedicate this special issue of Assmka to his honour. 


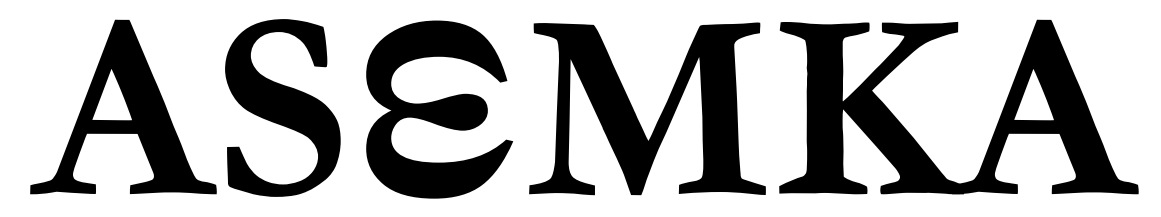

NUMBER 10

SEPTEMBER 2020 


\section{CONTENTS}

$\begin{array}{llll}\text { Editorial Committee } & \sim & \sim & \sim i i \\ \text { Editorial Staff } & \sim & \sim & \sim i i \\ \text { Editorial Advisors } & \sim & \sim & \sim i i \\ \text { Acknowledgements } & \sim & \sim & \sim i i i \\ \text { Subscription } & \sim & \sim & \sim i i i \\ \text { Advertising } & \sim & \sim & \sim i i i \\ \text { Submissions } & \sim & \sim & \sim i i i \\ \text { Back Issues } & \sim & \sim & \sim i v \\ \text { Grant Support } & \sim & \sim & \sim i v \\ \text { Dedication } \sim & \sim & \sim & \sim \\ \text { Foreword } \sim & \sim & \sim & \sim x \\ \text { Assmka: Editorial } & \sim & \sim & x i-x v i i\end{array}$

Articles

First Section - French

Britwum, A. G.

Insuffisances Théoriques Des Damnés De La Terre De

Frantz Fanon

$\sim$

$\sim 2-15$

Kodah, M. K.

Disculpation de Dieu dans le malheur des hommes:

Une lecture critique de Gouverneurs de la rosée de

Jacques Roumain $\sim \sim \sim 16-31$

Addo-Danquah, $O$.

Le récit de pensées: Une analyse comparative de Vol de nuit d'Antoine de Saint-Exupéry et La Condition humaine d'André Malraux

Kodah, M. K. \& Togoh, A. A. X.

Réactions des femmes face au conflit de genre dans C'est le soleil qui m'a brûlée et Tu t'appelleras Tanga de Calixthe Beyala

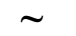

$\sim$

$\sim \quad 45-59$ 
Kudi, M. D.

La Littérature francophone face aux médias de télécommunication : Une nouvelle dynamique de la création romanesque, le cas de L'Énigme de retour et Tout bouge autour de moi de Dany Laferrière $\sim \quad$ 60-72

Gli, $M$.

Les faces du bonheur dans Vol de nuit d'Antoine de Saint-Exupéry $\sim \sim 73-85$

Krakue, S. P.

Christ haïtien : Gouverneurs de la rosée et La Bible $\sim 86-93$

Afari, E. S. K. \& Yegblemenawo, C. A. A.

Apports de la télésérie à l'amélioration de la compétence d'expression orale du FLE à l'école normale $\sim 94-116$

Bationo, J.-Cl.

Didactique de la littérature et littérature didactique:

l'exemple de la littérature africaine francophone en classe de langues étrangères au Burkina Faso

Second Section - English

Krakue, S. P.

Quod erat demonstrandum: A comparative study of narrative technique in Ama Ata Aidoo's Changes and Albert Camus'

Les justes (The Just Ones) 〜 $\sim$ $133-141$

Adjandeh, E. A.

Analysis of Wole Soyinka's Trials of Brother Jero in Relation to Ghanaian Religious Discourse

Sam, C. A.

Decolonizing the Postcolony: Of Men, Spatial Politics and the New Nation in WA Thiongo's Wizard of the Crow.

Kambou, M. K. \& Traore, S. A.

Manipulation and the popular uprising in Burkina Faso in 2014. 
De-Soura, A. Y.M.

Test-taking Strategies of University of Cape Coast Students of

French as a Foreign Language: a Case Study $\sim 191-216$

Kambou, M. K. \& Soma, L.

Local Culture and EFL Vocabulary Learning $\sim \quad 217-238$

Kabore, A. \& Nazortin, C.

Critical Analysis of the Place and Importance of Literature in the Teaching / Learning of English and in School Leaving Certificate Examination in Burkina Faso from 1985 to 2018

Malgoubri, I., Sawadogo, M. \& Kambou, M. K.

Digital Audio-visuals Aids and Listening in English as a

Foreign Language Classrooms

Osei, R. N. \& Inusah, $H$.

A Critique of the Images of Heaven in the Scriptures of the

Abrahamic Religions: An Existentialist Perspective $\sim$ 270- 282

Negedu, A. K.

Lexical Gaps and Ideological Shift in the Translation of

Chinua Achebe's Things Fall Apart as "Le Monde

S'effondre" in French $\sim \sim 283-297$

Talburt, $T$.

Political Transformation and Development in Africa:

Lessons from Achebe's Things Fall Apart

$\sim 298-313$ 


\section{FORWORD}

All the papers in this Volume were presented at a three-day Conference in honour of Professor Atta Gyamfi Britwum who turns eighty years in March 2021. Most of those years he spent at University of Cape Coast, having cut his teeth as a young lecturer in French language and Literature-in-French in 1974. After many years of an illustrious career in teaching, publication and extension, he bowed out at age seventy, but he didn't get the well-deserved rest he was entitled to; he continues to support his Department and the University as a whole. Today, Professor Britwum's name is associated with high standards of professionalism which earned him the nickname 'L'oracle'. Indeed, it is impossible to find another name universally acknowledged as embodying the excellence in French education offered at the Department of French, University of Cape Coast.

The decision to honour Professor Britwum couldn't have been taken at a more appropriate time. It was planned to coincide with the fiftieth anniversary of the publication of the Beautyful ones are not yet Born, Ayi Kwei Armah's first novel. Britwum never grew tired of reading, teaching and examining it. Such was his respect for Armah's craft. So, the three-day Conference was as much a celebration of Armah's contribution to the shaping of the African novel as it was a tribute to Professor Britwum's work as a teacher of literature of immense influence.

One only has to look at the titles of the papers published in this Volume to get an idea of how deep his influence runs at UCC and beyond. Most of the contributors once upon a time sat at the master's feet, but are now scholars in their own right keeping the flame of French scholarship burning bright (George Cooper: "Polished in a high degree, as each froggie ought to be/Now they sit on other logs, teaching other little frogs.") A good number of the papers are on Literature, nonetheless not limited to Armah's works. No Surprise there. Nevertheless, there are Language papers there too. No surprise here either, for the man to whose honour the Volume is dedicated is equally at home in both Language and Literature

\section{Lawrence $K$. Owusu-Ansah,}

Department of English, UCC.

A Disciple 


\section{$A S E M K A:$ EDITORIAL}

This Special Edition of $A S E M K A$, a bilingual literary journal of the University of Cape Coast, is published in honour of Prof. Atta Gyamfi Britwum, a revered Associate Professor of Francophone African Literature and Civilisation in the Department of French, U.C.C. It contains twenty (20) papers centred on diverse areas of teaching and research in the Humanities and on the theme of the Conference - Literature and the Humanities in the 21 Century: Interdisciplinary Perspectives - held in his honour by the Department of French, University of Cape Coast, Ghana, $13^{\text {th }}-15^{\text {th }}$ Mars, 2019. To reflect Prof. Britwum's area of research interest, the essays are arranged in two sections according to his dominant medium of instruction (French language) and speciality (Literature and Civilisation), followed by those in English language. The first section consists of a set of nine (9) essays in French spanning between themes in Literature and Language. The second section is made up of a set of eleven (11) essays in English which examine issues in literary studies, Language and Didactics, ICT and French Education, Philosophy, and Translation, among others. This special arrangement is however representative of the bilingual nature of the Journal.

\section{First Section}

Britwum, A. G.'s paper titled, “Insuffisances Théoriques Des Damnés De La Terre De Frantz Fanon", presents the Fanonian perspective as a complement to the African nationalism that informed anticolonial struggles. The study posits that African nationalism, populist in nature, for failing to target the capitalist economic base, which defines colonialism, ended up strengthening it. It concludes that Fanon's anticolonialist perspective, despite its overt radicalism, is not designed to allow a "bottom-to-top change" in colonial / capitalist society.

Kodah, M. K.'s paper titled, "Disculpation de Dieu dans le malheur des hommes: Une lecture critique de Gouverneurs de la rosée de Jacques Roumain", puts into question the responsibility of God in the suffering of men on earth and the capacity of man to make and unmake himself. The study aims at absolving God of the guilt of the miseries of men, and also questioning the atheistic or anti-religion denunciation of this narrative 
text since its publication. The study is accomplished through a critical reading and a thoughtful analysis of Jacques Roumain's Gouverneurs de la rosée within the analytical structure of literary studies and sociocriticism.

Addo-Danquah, O.'s paper, "Le récit de pensées : Une analyse comparative de Vol de nuit d'Antoine de Saint-Exupéry et La Condition humaine d'André Malraux", drawing inspirations from theorists such as Léon Edel (1961) and later Dorrit Cohn (1981), examines what Antoine de Saint-Exupéry's Vol de nuit by and André Malraux's La Condition bumaine respectively can offer on the side of representations of the interior life. The study is posited within the framework of narratological theories.

Kodah, M. K. \& Togoh Tchimavor, A. A. in "Réactions des femmes face au conflit de genre dans C'est le soleil qui m'a brûlée et Tu t'appelleras Tanga de Calixthe Beyala" examine the reactions of women to gender conflict in Calixthe Beyala's C'est le soleil qui m'a brulée and Tu t'appelleras Tanga. The study critically reflects on the various ways women in Beyala's C'est le soleil qui m'a brulée and Tu t'appelleras Tanga react to oppression and exploitation resulting from patriarchal domination. It therefore examines the sources and nature of this conflict, and how women react to it in the two novels. The study points to the fact that, much as conflict emanating from patriarchal oppression and male's domination in human societies is inimical to the rights of women, the methods used by the latter to free themselves from this state of being remain questionable, in that, these methods defy rational thinking and are also a kind of reversal oppression and domination which are equally unacceptable.

Kudi, M. D.’s paper, “La Littérature francophone face aux médias de télécommunication: Une nouvelle dynamique de la création romanesque, le cas de L'Énigme de retour et Tout bouge autour de moi de Dany Laferrière", seeks to examine how pertinent painting, photography, television, telephone etc. are to the production of the contemporary Francophone novel. The study focuses on L'Énigme de retour (2009) and Tout bouge autour de moi (2011). The analysis is based on the perspective of literary intermediality propounded by Jürgen E. Muller which is characterised by an interaction between telecommunication media and literary text. The study establishes through these selected novels that these media forms are not simply another form of expression in the novel but rather a lens through which the story is narrated. 
Gli, M.'s paper titled, "Les faces du bonheur dans Vol de nuit d'Antoine de Saint-Exupéry", analyses the faces of happiness in Antoine de Saint-Exupéry's Vol de Nuit. The study is conducted through thematic approach. This approach is complemented by Maslow's theory of human needs. The collection of data or the collection of information is purely documentary. The study therefore seeks to establish a link between individual happiness and collective happiness in Saint-Exupéry's selected narrative text.

Krakue, S. P.'s paper, “Christ haïtien : Gouverneurs de la rosée et La Bible", attempts to question Jacques Roumain's Gouverneurs de la rosée in order to elucidate the novelist's use of the biblical text in his creative activity. The study demonstrates that Jacques Roumain's narrative text turns out to borrow biblical ideas not only to develop his plot but also to design his main character.

Afari, E. S. K. \& Yegblemenawo, C. A. A. in “Apports de la télésérie à l'amélioration de la compétence d'expression orale du FLE à l'école normale." examine the impact examine the impact of the use of serial movies as teaching aid on oral expression of French language learners in Colleges of Education in Ghana with the aid of smartphones. The study discovers that the use of serial movies in teaching French boosts learners' performance in oral communication. It therefore recommends that serial movies could be used in teaching French language lessons in order to enhance the oral communication competencies among learners.

Bationo, J.-Cl.'s paper titled, "Didactique de la littérature et littérature didactique : l'exemple de la littérature africaine francophone en classe de langues étrangères au Burkina Faso", shows not only how to teach literature in language class but also how to use didactic literature to develop social skills among learners to reduce vandalism, school violence, negative stereotypes, misunderstandings of intercultural nature while cultivating social peace and living together in a context of internationalization, globalization and digital revolution. The paper focuses on francophone African Literature and posits that methodological approach used for the didactic transpositions of literary content is based on the new orientation and the redefinition of the objectives of language teaching and on the didactic models of the aesthetic reception of didactics of literature which requires putting the learner in intensive interaction with the text and motivating $\mathrm{him} /$ her to express himself/herself on his/her reading experiences. 


\section{SECOND SECTION - ENGLISH}

Krakue, S. P.'s paper titled, “Quod erat demonstrandum: A comparative study of narrative technique in Ama Ata Aidoo's Changes and Albert Camus' Les justes (The Just Ones)", demonstrates through textual analysis, how in Ama Ata Aidoo's Changes and Albert Camus Les justes, the authors resort to a specific form of irony to bring the discussion of issues raised to a conclusion. The technique consists in demonstrating clearly a huge discrepancy between a "fine" idea and its practical usefulness. Both authors successfully use narrative technique. Albert Camus demonstrates the hollowness of the idea of fighting for justice through revolutionary violence and Ama Ata Aidoo similarly demonstrates the fatuousness of the theory of women-emancipation-through-polygamy.

Adjandeh, E. A. analyses selected reports in Ghanaian media in relation to the clergy and identifies how Wole Soyinka's theme is reflected in these media in her paper titled, "Analysis of Wole Soyinka's Trials of Brother Jero in Relation to Ghanaian Religious Discourse". The study seeks to examine the extent to which themes in Soyinka's Trials of brother Jero play out in religious discourses in Ghana. The global nature of the issues problematized by Wole Soyinka also comes out through this study as the work set in Nigeria is analyzed in relation to the selected articles set in Ghana. The paper relies on a content analysis of Trials of Brother Jero and similar themes presented in the selected articles, and makes a few recommendations on how these religious issues could be partially, if not wholly, resolved in Ghana.

Sam, C. A.'s paper, "Decolonizing the Postcolony: Of Men, Spatial Politics and the New Nation in WA Thiongo's Wizard of the Crow", examines how Ngugi Wa Thiongo's Wizard of the Crow blatantly explores Africa's complicity in a seemingly cyclic colonization in the $21^{\text {st }}$ century and its attendant consequences for the total liberation of Postcolonial Africa. The study examines the correlation between masculine representations, spatial reorganization and futurity as alternative ways in thinking about Africa's future through Bakhtin's theory of the carnival and other such concepts as polyphony and the grotesque. The result of the analysis is that the correlation between forms of communities and forms of masculinities is an indication of a vision of hope for Postcolonial Africa. 
Kambou, M. K. \& Traore, S. A. in "Manipulation and the popular uprising in Burkina Faso in 2014", analyse the different discourses in the build-up to the popular uprising in Burkina Faso on the $30^{\text {th }}$ and $31^{\text {st }}$ October 2014. It attempts to clarify how political and civil society leaders use language and other non-linguistic elements to influence the ordinary citizens' minds and, indirectly, their actions. The analysis is premised on Van Dijk's (2006) Sociocognitive approach. The paper analyses the cognitive, the social and the discursive dimensions of manipulation in six political speeches (two speeches from Civil Society, two from the ruling party and two from the political opposition). The results suggest that the three groups manipulated their audiences, and finally, the ruling party lost following the resignation of the then Head of State, making way for a Transition government to take over the reins of governance.

De-Souza, A. Y. M.'s paper “'Test-taking Strategies of University of Cape Coast Students of French as a Foreign Language: a Case Study.” seeks to provide a description of test-taking strategies that may inform teaching and learning of French for better output in tests against the background that Ghanaian students of French as a foreign language deploy strategies that are not adequate enough in answering test items in French. The study examines data gathered right after a French test by level 200 students, using recollective verbalization protocols.

Kambou, M. K. \& Soma, L. examine in their paper titled, "Local Culture and EFL Vocabulary Learning”, the influence of learners' culture on foreign language vocabulary. The paper seeks to demonstrate that there is a link between culture and lexico-semantic errors committed by learners of English as a foreign language among Dioula speaking students in Burkina Faso. A language test composed of two written activities was used as the data collection instrument. The results revealed that the Dioula speakers' English is influenced by their culture. These results have some pedagogical implications. They, therefore, suggest that we adapt the teaching of EFL vocabulary to learners' culture.

Kabore, A. \& Nazortin, C. in "Critical Analysis of the Place and Importance of Literature in the Teaching / Learning of English and in School Leaving Certificate Examination in Burkina Faso from 1985 to 2018", analyse the types of texts given at the "Baccalaureate A" written examination in the last thirty years. In this study, quantitative and qualitative 
data are collected. Baccalaureate written English papers are the main focus of our collection. Teachers and supervisors are interviewed. The study is grounded on "Reader-Response Theory" which stresses the interactions between the reader and the text. The results of the study show that the great majority of texts proposed for "Baccalaureate A" examination, in the last thirty years, are non-literary texts.

Malgoubri, I., Sawadogo, M. \& Kambou, M. K.’s paper titled, “Digital Audio-visuals Aids and Listening in English as a Foreign Language Classrooms", is an experimental study which investigates the potential of digital audio-visuals to improve the listening skills of EFL learners in secondary schools in Burkina Faso. On the assumption that learners born around the year 2000 are digital natives, the researchers try integrating smartphone-friendly audio-visuals in their EFL classrooms in a four-week experiment involving one Experimental Group and one Control Group. The experiment aims at gauging the effectiveness of those aids operated via students' smartphones in improving learners' listening and speaking skills. Independent T-tests were used to compare the groups and Sample Paired TTests to make comparisons within groups. The study suggests that, if appropriately used, smartphones are excellent devices for language teachers and learners in this digitizing world.

Osei, R. N. \& Inusah, H.'s paper, “A Critique of the Images of Heaven in the Scriptures of the Abrahamic Religions: An Existentialist Perspective." Critically examines the scriptural images of heaven as captured in the Abrahamic religions - Judaism, Christianity and Islam - from the existentialist perspective. The paper argues that the idea of life beyond this earthly existence for all human beings in a specially prepared location by God for eternal happiness for those who obey His commands on earth called Heaven, as propounded by the Abrahamic Religions, throws up a lot of problems, especially from the existentialist perspective. The study concludes that the scriptures' constructs of heaven appear self-contradictory and fail to strike a chord with the contemporary image of the ideal society when perused from the existentialist perspective and should, therefore, be discarded.

Negedu, A. K.'s paper "Lexical Gaps and Ideological Shift in the Translation of Chinua Achebe's Things Fall Apart as "Le Monde S'effondre" in French." examines the ideological divergence between the title of the original text and the title of the translation, following an observation 
that in translating Chinua Achebe's Things Fall Apart, Michel Ligny translates directly Igbo terminologies, realities and beliefs into the French language. The paper concludes that the ideology that the translated title projects to French-readers is totally different from the ideology that the original title projects to English-readers.

Talburt, T., in "Political Transformation and Development in Africa: Lessons from Achebe's Things Fall Apart", formulates critical perspectives on the significance of Achebe's novel for the socio-political and economic transformation and development of the African continent. The paper challenges one of the central assumptions in this story that Africa falls apart as soon as it comes in contact with Europe. It questions aspects of political conservatism exhibited in Okonkwo who is suspicious of fundamental changes to his society. The discussion is based on the jollof rice principle of political hybridisation of development which proposes the amalgamation of Westernised and non-Western ideas and systems, in order to achieve economic development, rather than totally rejecting Westernisation in its entirety. The study uses examples of Western-style democracy and State intervention in Africa to demonstrate the significance of embracing some aspects of Westernisation through political hybridisation. 





\title{
Quod erat demonstrandum: A comparative study of narrative technique in Ama Ata Aidoo's Changes and Albert Camus' Les justes (The Just Ones).
}

\author{
Sylvester Petrus Krakue \\ University of Cape Coast, Cape Coast, Ghana.
}

\begin{abstract}
Authors of fictional works often have recourse to irony whereby they subtly indicate their disapproval of certain ideas or courses of action. Irony is a rather complex and wide-ranging phenomenon. However, in both Ama Ata Aidoo's Changes and Albert Camus Les justes, the authors resort to a specific form of irony to bring the discussion of issues raised to a conclusion. The technique consists in demonstrating clearly a huge discrepancy between a "fine" idea and its practical usefulness. This study, through textual analysis, aims to show how the two aforementioned authors successfully use this narrative technique. Albert Camus demonstrates the hollowness of the idea of fighting for justice through revolutionary violence and Ama Ata Aidoo similarly demonstrates the fatuousness of the theory of women- emancipation-through-polygamy.
\end{abstract}

Keywords: literary creation; literary irony; narrative plot; narrative technique; textual criticism.

\section{Introduction}

Irony is a wide-ranging phenomenon. Most people know it as a figure of speech whereby a speaker utters the opposite of what they actually intend to communicate. For example a teacher might say to a student who comes to class late, "That's very good. Keep coming to class late." The immediate context, aided, perhaps, by the facial gestures of the teacher will enable all the students to understand what the teacher really means to communicate namely that coming to class late is bad and that the student in question ought to do away with that attitude. 
This kind of irony is sometimes referred to as antiphrasis or semantic inversion. However, antiphrasis is not the only form of irony. As Linda Hutcheon (1995: 60 - 61) has pointed out, "In an ironic utterance, the 'unsaid' (which others might call the 'ironic meaning') need not be in logical contradiction to the "said" (or literal meaning). Similarly, French linguist, Philippe Hamon, explains in his book, l'ironie litteraire (Literary Irony) (1996: 40):

In an ironic discourse, the explicit discourse says something other than the implicit discourse that the ironist wishes to carry across. The discourse has a double significance. Its intent is not solely informative but also evaluative. If we are to account for the complexity of ironic texts, then rather than talk of [ironic] communication as [being] structured on a relation of contradiction (a vs non-a), we should talk of discrepancies, of tension fields.

In other words, irony happens in discourse, when, in the course of a communication, a tension is introduced or perceived between the said and the unsaid, the stated and the meant, the explicit and the implicit, text and intertext, a sound and its echo, a position and its enacting, an utterance and its enunciating, the ostensible and the actual. What we are calling "tension" here might also be called discrepancy or incongruity. In the two works we are about to study, the narrative technique consists in demonstrating a huge discrepancy or incongruity between ideas that are initially considered 'great' and their practical usefulness.

The Latin phrase "quod erat demonstrandum" meaning "which was to be shown" or "thus it has been shown or proved" is normally placed at the end of a mathematical proof or philosophical argument to indicate that the proof or argument is complete. In Ama Ata Aidoo's Changes and Albert Camus' Les justes, the narrative plots present similar patterns: a discussion or debate is started, some conclusion or decision is reached, and this decision is then put to a pragmatic test to demonstrate its futility.

So, in Changes, a lot of exchanges go on between Esi Sekyi, the protagonist, and her friend, Opokuya, on the question of Esi's intention to divorce her husband, Oko. Opokuya counsels against being single for the simple reason that Esi would not be able to handle the subsequent loneliness. On her part Esi Sekyi is both decided and determined: marriage is worth considering only if the man would accept her life style. She counters all the arguments of her friend, Opokuya, thus: "Me? Never! I could not bear it...Another husband to sit on my back all twenty-four hours of the day? The same argument about where a woman's place is? ... Ugh, Opukuya, I couldn't." 
(Aidoo 1994: 45). The argument that had raged between Esi and her friend Opokuya centered on the woman's independence or freedom in the context of marriage. Esi insisted marriage was worth considering only if the man would accept her life style: "I'm sure there will be no solution for me. Unless I meet a man who is prepared to accept my life style.” (p. 47).

But Opokuya is as convinced as Esi that this kind of mindset will most certainly lead to trouble: unbearable doses of loneliness for Esi Sekyi: "Your lifestyle? Esi, if you continue in that way, you will get in trouble. Because, my dear, no man is totally going to accept your lifestyle..." (p. 47). When Esi tries to suggest that it is only in Africa women cannot have their way all the time, Opokuya frankly puts it to her that her conception of feminine emancipation is simply utopian:

Esi, no society on this earth allows that...You just can't have everything your way, and not expect to be lonely, at least some of the time (...) No matter what anybody says, we can't have it all. Not if you are a woman. Not yet. (p. 48)

In the face of all these warnings, Esi, the protagonist remains unperturbed. Defending a policy of absolute freedom for the woman even in marriage, she counters all the arguments advanced by her friend, Opokuya, thus: "IIf the one to be a fool to make a marriage work is supposed to be the woman], I am having none of it. P.e.r.i.o.d.” (p. 48)

Indeed, in pursuance of her hard stance on a woman's place in marriage (i.e. unfettered freedom for the woman) Esi agrees to become the second wife of Ali, a man who is already married to Fusena, a mother of three (p. 65). She then rationalizes away this step by telling Opokuya: "Ali is wonderful. And so understanding of the kind of woman I am." (p. 91). Then in a final note of triumph for absolute freedom of the woman even in marriage, Esi damns monogamy as she tells her friend: "Opokuya, monogamy is so stifling." (p. 91).

It is clear that Esi stands for freedom, change and an alternative lifestyle even if it is polygamy that will bring this about. One is so vividly reminded of the French poet, Baudelaire, who, in his desperation to find something new at all costs, was willing to try the depths of the unknown beyond death whether hell or heaven. ${ }^{1}$

Accordingly, Esi Sekyi does indeed get married to Ali as a second wife and initially finds the marriage ideal as it procures for her the dream change she has so desperately desired. The narrator comments thus: 
In all her basic hopes for marrying a man like Ali had been fulfilled. Ali was not at her back every one of every twenty-four hours of every day. In fact, he was hardly ever near her at all, in that sense she was extremely free and extremely contented. She could concentrate on her job and even occasionally bring work home. (pp. 133 - 134)

In the course of the story, however, Esi will discover the inadequacies of her system. The novel actually illustrates or shows convincingly a disparity between method and results, a gap between dream and reality. For the narrator informs us that although Esi's bold experiment initially delivered a welcome change, pretty soon, other changes, neither welcome nor healthy also occurred. For example, there was the problem of the almost perpetual absence of Ali, the new husband. The narrator explains: "There were many weeks in a row followed by weekends when she could do with company without her having to go out and look for it (...) Ali was supposed to be her husband and she missed him." (p. 135).

In practical terms, this almost perpetual absence of Ali resulted in desolation and loneliness in more doses than Esi could conveniently handle. The narrator explains:

That year (year of marriage to Ali) turned out to be perhaps the most desolate time Esi had spent in all her life. She not only felt tired like everyone else at that time of the year but she was also restless and lonely... (p. 137)

By the $23^{\text {rd }}$ of December, Esi was a nervous wreck...

By New Year's Eve, Esi had decided that she needed some tranquilizers for her nerves. (p.139)

Yet this was the lady who, in the days of her marriage to Oko, had gone as far as to desire that her man run after other women just so she might have more time to herself and for her career (p.37). Clearly then, her theory of womenemancipation-through-polygamy did not, in the long run, procure the expected satisfaction for her.

Indeed, beyond taking tranquilizers to calm her nerves, Esi, the narrator informs us, had reviewed her marriage to Ali and concluded that this was a complete dead end. (p. 145)

Another unwelcome change that came along with the great change was Esi's heightened awareness of the fact that she was no more than a mere mistress to Ali in spite of the marriage ceremony she and Ali had gone through. The narrator explains thus: 
'Esi sat and remembered all the other times in the past that Ali had announced he had to leave her after a short or long stay and how intensely she had hurt each time then.'

'I must be running home...'

'I have to go home...'

'I'll phone from the office before I go home...'

'I'll pass by on my way home...'

And they had both known that he had always meant where he and his wife Fusena, and their children lived (p. 146)

The women-emancipation-through-polygamy formula brought no practical fulfilment to Esi Sekyi. We see this through Esi's reaction to the news that Ali, her polygamous husband, had got a new, pretty, lady secretary. According to the narrator:

Esi, continued sitting in the new car outside her own gate [...] She was having arguments with Ali, with Opokuya and herself about Ali's new secretary.

So, what of it if Ali occasionally dropped his secretary home.

But it was not occasional. It sounded like every day.

So, what of that?

But I don't want him to!

Why not?

It hurts

Does it?

Terribly!

Well just remember that if a man can have two wives...then he can have three...four wives...

And so on and on and on...Plus remember...

Esi did not want to remember anything. She got out of the car, opened the gate, entered the compound and parked it for the night. (pp.151 - 152)

It can thus be seen that the opening paragraph of the last chapter of Changes captures the essence of what the novel demonstrates: the gap between the "fine" idea and its practical usefulness.

All Esi was aware of was desolation. As for her mind, it was completely blank. She did not know what to do [...] what made everything bad was that she had been aware that her 
grandmother and Opokuya had tried very hard to warn her.

She had just been a real fool. (p. 158)

It is this same scenario of demonstrating the futility or jejuneness of an apparently 'great' idea that we encounter in Albert Camus' Les justes. In Les justes, a group of young idealist revolutionaries seek justice for everyone in society especially the weak and the vulnerable. In the quest for justice for all, the members of the group find that there is a question they have to settle before they can proceed further: "Is it right to sacrifice human lives in the quest for justice for all?"

After very bitter discussions the young Revolutionaries agree that only the person they considered to be the incarnation of injustice and tyranny deserved to die and that the one of their number who did the killing should refuse any presidential pardon and so die as an innocent person and not as a criminal. The thinking of the members of the Revolutionary Socialist Party was that once the murderer of the Grand-Duke accepted to die, he would be absolved of any crime or guilt and could no longer be regarded as an assassin or criminal. As the story unfolds in the play, this solution arrived at by the Revolutionaries proves rather inane and jejune and not really worth the candle.

Kaliayev, the party member chosen to throw the bomb does indeed throw the bomb and succeeds in killing the Grand-Duke of Russia. Subsequent to this, he is incarcerated. Inside the prison cells, however, Kaliayev has three successive encounters that reveal the pointlessness of the position of the Revolutionaries.

In the first encounter, Kaliayev fails woefully to convince Foka - a commoner and a member of the lower classes of the society - of the need to have killed the Grand-Duke Serge.

Kaliayev tries to convince Foka that the quest for justice and better living conditions here on earth is not a matter of trusting God or hoping for some future kingdom of God. But Foka confesses he does not see the point in Kaliayev's action (of killing the Grand Duke):

It's never right to go too far...

I don't quite get it.

All this is not normal. Why will anyone get himself locked up in prison because of some story of saints and carts... (p. 102)

And then there is something else. (p. 103)

$[\ldots]$

I'm the one who hangs condemned prisoners... (p.105) 
For each prisoner hanged, they reduce my sentence by one year.

It's a good deal. (p.105)

When Kaliayev concludes by calling Foka an executioner, Foka retorts by asking: "Well...what about you?" (p. 106). So Kaliayev's action (and by extension, the solution arrived at by the Socialist Revolutionaries) only earns him the scorn of a person supposed to be a beneficiary. Worse still and rather ironically, Kaliayev would be executed by this member of the masses.

Within the same prison, Kaliayev has a second encounter - with Skouratov, the head of the Police Service. In that encounter, Kaliayev insists that he is no murderer or assassin and that he is a prisoner of war, having killed, not a man but tyranny. (pp. 108 - 109). To this, the police Chief replies: "Certainly, but it was a man that got hit by the bomb you threw. ... a man got killed...there was blood...plenty of blood [...]." (p. 110)

Once again, one finds that Kaliayev's argument fails to fly, because even though he claims it was tyranny and not a man he threw the bomb at, in reality, the tyrannical system was still in place and had not suffered so much as a dent. Neither he, Kaliayev, nor members of his Revolutionary Party, nor ordinary members of the lower classes of the society had gained any more freedom than before. It was rather he, Kaliayev, who was soon going to be hanged for murder (even if he refused to acknowledge his terrorist act as murder). In effect, the encounter with the Police Chief Officer, Skouratov, exposed the terrorist act of the Revolutionaries to be mere idealism.

In yet a third encounter, this time between Kaliayev and the GrandDuchess, the wife of the late Grand-Duke, Kaliayev is forced to admit that revolutionary terror does not achieve justice for anyone nor does it improve anyone's lot.

The Grand Duchess reveals to Kaliayev that the late Grand Duke was indeed kinder and more sympathetic towards the common people than the nephews who were spared. The Grand Duchess reasons that on that score, Kaliayev had also been unjust in his judgment (p. 119). And then Kaliayev admits that he has compassion for the Grand Duchess (p. 122) who is now in great pain as she mourns her late husband. So, one is left wondering if Kaliayev could point out one tangible good issuing from revolutionary violence.

Indeed, away from the prison cells the terrorists themselves are trying without too much success to sustain the idea of the usefulness of revolutionary terror. Dora, the only female member of the Revolutionary Party, thinks and frankly confesses: "...if the only solution is death we are not on the right path. The right path is the one that leads to life, to the sun. We can't be feeling cold 
forever." (p. 139). When the leader of the group explains that the path they have chosen also leads to life, albeit for others, Dora remains skeptical: "He (that is Kaliayev) is probably dead so that others may live Ah! Boria, and if the others did not live? What if he died to no purpose?" (p.138). For Dora, there is no guarantee that terrorist violence will achieve any good for the terrorists themselves or for any other persons: "Are we sure that no one will go further? $[\ldots]$ others may perhaps use what we have done as an excuse and go on to kill and not pay with their lives." (p.139)

Yet again, through Dora, we see that the terrorists' solution has no real practical value. Dora tries desperately imagining a happy Kaliayev going gladly to the gallows to be hanged and she explains why Kaliayev must be in a joyous mood: "...it would be too unfair that having renounced happiness in life in order to better prepare to be sacrificed, he should then not know happiness at the moment of his death." (p. 149). Unfortunately, neither Dora nor Kaliayev nor any of the Revolutionaries felt or even looked happy. Indeed, the group's leader, Annenkov, wept (p. 150) and yet the political system they were trying to overthrow was as solidly in place as ever.

The inanity of the group's violence had, in fact been predicted by one of them, Stepan, who at the time discussions were going on to arrive at a conclusion had warned that: "Sometimes, not killing enough is tantamount to killing for nothing." (p. 66).

Stepan, at the time had been a lone voice that was roundly condemned and rejected but now near the end of the story he seemed so vindicated by the turn of events. It must be pointed out, though, that what Stepan was advocating at the time - indiscriminately killing everyone in sight including innocent children - was equally not a viable option.

\section{Conclusion}

In conclusion, we see that Albert Camus' play, Les justes (The Just Ones), and Ama Ata Aidoo's Changes both demonstrate convincingly that great ideas are not necessarily practically useful ideas. In this way the two works respectively disagree with the idea of achieving justice for all through terrorism and that of achieving women emancipation through polygamy.

\section{Note}

1. In a rather long poem entitled THE VOYAGE and included in his famous collection of poems, Les fleurs du mal, Baudelaire writes in the closing stanzas:

O Death, old captain, time is up! Let's weigh anchor

We are bored in this country, $\mathrm{O}$ death! [...] 
$[\ldots]$

We want, so ardently this fire burns within our soul, To plunge deep down into the abyss, Hell or Heaven, what does it matter?

Into the depths of the Unknown to find something new!

\section{References}

Aidoo, A. A. (1994) Changes. Accra: Sub-Saharan Publishers.

Baudelaire, C. (1972) Les fleurs du mal. Paris: Le livre de poche.

Camus, A. (1950) Les justes. Paris: Gallimard.

Hamon, P. (1996) L'ironie littéraire. Paris: Hachette. 